\title{
The Indonesian Diaspora in Europe: Culinary as Cultural Identity and Tourism Promotion in Paris, France
}

\author{
Nararya Narottama \\ Management of Tourism \\ Sekolah Tinggi Pariwisata Bali Internasional \\ Denpasar, Indonesia \\ nararya.narottama@gmail.com
}

\author{
Eka Sudarmawan \\ Hotel Management \\ Sekolah Tinggi Pariwisata Bali Internasional \\ Denpasar, Indonesia
}

\begin{abstract}
Today, the Indonesian diaspora has spread across the world, including in Europe. In the process of this dispersion, the Indonesian diaspora always try to maintain various forms of their cultural identity, including their culinary culture. In this context, the Indonesian diaspora continue to introduce and spread the richness of Indonesia culinary culture abroad. This study wanted to reveal how the Indonesian diaspora in Europe attempting to build their national cultural identity through culinary? Including, the implementations, opportunities, and challenges, which they must face in these cultural preservation efforts? This study focuses on the Indonesian diaspora spread across Europe, particularly the city of Paris, France. The method used in this research is qualitative descriptive, through direct and indirect interviews and participative observation. The initial hypothesis is that the Indonesian diaspora in Europe has an open communal character, and they have a sense of pride in the richness of Indonesian cuisine, it also maintaining a sense of nationalism and the rise of national cultural identity.
\end{abstract}

Keywords - Indonesian diaspora, culture, culinary, national identity

\section{INTRODUCTION}

Now we are in an era of globalization, a contemporary concept which one of it's characters is Ethnoscape, a mobilization, or the spread of humans across the world (Appadurai, 1996). The process of massive mobilization in the last three decades happen for a variety of motives. This process has created new opportunities for the actors involved. In line with this issue, it estimated there are more than eight million Indonesian diaspora scattered around the world (Natalegawa, 2013) in more than 90 countries (Tempo, 2015). This amount is quite small compared to the number of the Chinese diaspora (about 70 million) and India (60 million people). Nevertheless, the Indonesian diaspora remains a valuable asset for the country's development. Former President of Indonesia, Susilo Bambang Yodhoyono, in his speech at the Congress of Indonesian Diaspora II in Jakarta said that the Indonesian diaspora around the globe is government's strategic partner and their existence should not be ignored (Kompas, 2013).
The Indonesian diaspora abroad came from different backgrounds. They work as experts, professionals, musicians, artists, academicians, students and merchants. If the government put enough attention, governance and good regulatory, the Indonesian diaspora will become an economic, social and political strength for the nation of Indonesia. Thus, the Indonesian diaspora acctually has a broad range of potentials that could be developed. In fact, some of the Indonesian diasporas has been successfully achieved international recognitions, one of which is Anggun C. Sasmi, a singer who managed to become a famous diva in Europe, especially in Paris, France.

Paris, also knowned as The City of Lights, is the largest city and the capital of the France. Historically, the city of Paris is the capital of the Kingdom of France and also serve as the center of the economy, politics, tourism and culture of France. City of Paris has many art museums, historic buildings and also modern buildings. The city landscape is a mix between modern and elegant classic taste, as well as a symbol of romance and love. City of Paris is a multi-cultural city, where $20 \%$ of the population are from outside France and its descendants. In 1990, the number of Asian immigrants reached 108,000 inhabitants (Guillon, 1998), and is currently estimated at more than 2,000 Indonesian diaspora living in Paris (France 24, 2009). The Indonesian diaspora in Paris to work in various sectors, including government related, economics, engineering and arts. However, way of life in other countries would be different from life in their home country.

The Indonesian diaspora in Paris came from various ethnic groups and regions in Indonesia. They form communities that are considered able to maintain, strengthen and represent their existence in the city. One of the examples is a community of Sekar Jagat Indonesia (SJI) which focused on the art of Indonesian dances and performances. At the beginnning, the community was led by the Balinese diaspora in Paris, but had gradually increased its members from various tribes and ethnicities across Indonesia. In line with the Balinese diaspora in Paris, the other Indonesian diaspora also participated plays a dual role in contributing their efforts to introduce the traditions, art and culture of Indonesia to French society. In addition 
through the art of dance, one of these efforts is to introduce the richness of Indonesian cuisine in Paris.

The term diaspora in the modern sense began to be used and received serious attention since the end of the 20th century, especially with regard to transnational relations. The word diaspora comes from Ancient Greek, which means 'seeding' or 'sowing'. The word "diaspora" consists of a verb, namely: 'speiro' (which means sowing) and preposition 'dia' (which means above). In modern terms applied to the human diaspora refers to the migration and colonization (Cohen, 1997). In further developments, the term diaspora began to used in area of political issues, nation identity, art and culture, intellect, religiusme, nation loyalty to the culinary. The term diaspora can also mean a nation or ethnic, by forced or voluntarily leave their country or their ethnicity, including their spread across the world, the spread of culture, as well as the genetic change from the impacts. Diaspora is a social phenomenon that occurred in various parts of the world, and experienced by various ethnic groups. Diaspora does not happen only physically and material, but also affect the (socio) cultural and psychological of the actors (Rahardjo, 2010).

Culinary most of the time (even not always) become a feature, or a marker of cultural peculiarities in a country or a region. Indonesian culinary often become a reference, because it is able to represent the local cultural richness of the Indonesian archipelago in the eyes of foreigners. The richness of Indonesian culinary reflects the cultural wealth of the Indonesian nation. It is an attempt by the Indonesian diaspora to continue building an Indonesia's national cultural identity in other countries, while enhancing a sense of nationalism and pride in their cultural roots of their respective regions.

The main objective of this study is to explore and determine, the extent to which the efforts of the Indonesian diaspora in Paris to build their national identity through the Indonesian culinary. Including the extent to which the Indonesian culinary diaspora nationalism is able to represent Indonesia in Paris and France in general, and to know how the actual implementation of these efforts. The main focus of this research is the Indonesian diaspora in Paris, France. Hopefully, this research can be a reference of the study related to the existence of Indonesian diaspora and the role of Indonesian culinary to the development of their national identities in Europe, especially in Paris, France.

\section{METHOD}

This research is a descriptive qualitative research, with phenomenological approach. Through this approach, the researchers conducted an intrepretif analysis, to explore, and try to uncover the meaning of an action, event or phenomenon that is based on the awareness of individuals in their natural environment (natural setting). Data collection techniques includes: in depth interviews with 10 selected informants whiche were considered to have an important role on the theme in question, participative observation in the site in the period 2011-2012, on-line observation, and documentation. Writing period the research was conducted between the August to October 2016. The main focus of this research is the Indonesian diaspora in Paris, France, especially those who have an interest in the events, arts, cultures and culinary of Indonesia.

\section{RESULT}

At the beginning of the 20th century, along with advances in information and technology, communication and transportation, the popularity of globalization and the spread of various ethnicities of people across the country (ethnoscape) as proposed by Appadurai (1996), then the use of the term diaspora have also increased. Primarily to discuss the spread of the phenomenon throughout the world, mobility and international migration, including international efforts to use migrants as a strategic asset by their country of origin.

India is one country that successfully manage the potential of the their worldwide diaspora to establish mutual relations between nations and countries. In the United States, the Indians are the second largest ethnic groups in the country. In the past two decades, Indian diaspora in America succesfully become a catalyst of ethnic relations between the two countries. Indians, who managed to become part of a high class society in America, routinely lobbied the government in terms of American domestic political relations with India. The same thing happened to the Indian diaspora in Malaysia, Singapore and Australia (Singh, in Hasanah, 2013).

The Indonesian government began to realize the potential power of the Indonesian diaspora around the world. For this reason, in July 2012, the first Congress of Indonesian Diaspora was held in America, it invites all Indonesian diaspora from various countries. The congress was organized by the Indonesian Foreign Minister at the time, Mr. Marty Natalegawa and Indonesian Ambassador to the United States, Mr. Dino Patti Djalal. The congress formulated the formation of Indonesian Diaspora Network (IDN) as a form of intellectual awareness of Indonesian diaspora. The government's fears of the impact of brain drain, turns into brain gain.

In 2013, the second Congress of Indonesian Diaspora was held. This meeting have an agenda to establish twelve Indonesian Diaspora Task Forces, as a commitment of cooperation between the government, the Indonesian diaspora and related agencies. These task forces has engaged in the fields of energy, employment, immigration, citizenship, education, science and technology innovation, urban livable, green economy, public health, business, investment, aerospace, youth and Indonesian cuisine.

Task force of culinary has a duty to encourage the formation of Indonesian cuisine consortium, together with the government and the private sector in order to build more Indonesian restaurants around the world. this task force has responsibility to promote the Indonesian culinary overseas.

Culinary diversity is one of the cultural wealth of a nation. In the realm of international cultural diplomacy, cultural image of a nation can be done through a variety of aspects, including sports, education, arts, and culinary. In fact, culinary is also considered as the most recognizable attributes of national identity of a nation. Many countries successfully used culinary as an agent of their cultural diplomacy globally. The majority of the population in many countries around the world know 
very well that the Sushi and Sashimi as Japanese food, Pizza and Spaghetti are comes from Italy, Tom Yam from Thailand, Tacos and Tortillas from Mexico, Kimchi from Korea, as well as Escargot, Baguette and Wine as typical French food and drink. When our senses heard, seen, or tasted these foods, the perception of our subconscious is immediately moved to the ways of living and culture of the country of origin of the food.

The food is no longer just a belly filler, but has evolved into a symbol of nationalism, prestige and social status, as well as promotional nature. The uniqueness of the foods above, becomes a mirror of cultural richness and uniqueness of the its countries. Thus, these foods became the national identity and nation's proud.

Indonesian culinary, offers a variety of unique gastronomic experiences. The use of tropical spices, cooking methods and a unique ways of presenting, combined to produce exotic taste and aroma. Indonesian culinary actually quite well known in foreign countries. It has at least three well known culinary globally, namely Rendang, Nasi Goreng and Satay. Rendang managed to be the best dish in the world or "World's Most Delicious Food" (CNNTravel, 2011). In addition, a typical Indonesian drink: "Luwak" coffee, also managed to become the most expensive coffee in the world (Forbes, 2006). Indonesian culinary have a huge potential to be accepted by the international community, and it can opens the way for the promotion and tourism development of the country, especially in the realm of culinary tourism.

Historically, the spread of the Indonesian diaspora accross the world was in the setting of pain and suffering. Mark Vink (2003) in his article entitled "The World's Oldest Trade: Dutch Slavery and Slave Trade in the Indian Ocean in the Seventeenth Century", which was published in the Journal of World History 2003 declared, in the era of colonialism, the network of the slave trade in Indonesia was around two main axes, namely in Bali and Makassar. Makassar was a major transit port for slaves from Borneo (Kalimantan), Sulawesi, Buton (Butung), and the islands of the Northeast, as well as the islands of Southeast East: Lombok, Sumbawa, Bima, Manggarai and Solor. The kingdoms in Bali is not only a standalone slave exporter, but also distributed slaves from East Indonesia, and New Guinea (Irian Jaya).

From the nearly 10,000 Indonesian slaves brought to Batavia by Asian ships between 1653 and 1682, 41.66\% $(4,086)$ were from South Sulawesi, $23.98 \%(2,352)$ of Bali, $12.07 \%(1,184)$ of Buton, $6.92 \%$ (679) from the islands in the Southeast, and $6.79 \%$ (646) of the Moluccas (Ambon and Banda). The same proportion of Indonesian slaves can be found in the Dutch colony in Indonesia and at the Cape of Good Hope, Africa, where South Sulawesi, accounted for $46 \%$ and Bali for $6.6 \%$ of 166 Indonesian slaves which were imported in the last three decades in the seventeenth century (Vink, 2003).

Between 1680 and 1731, 30.2\% (201) of 666 slaves importers brought to the Cape of Good Hope, Africa, originated from Indonesia, $24.8 \%$ (165) of India, and $22.1 \%$ (147) were from Madagascar and other parts of Africa. Slavery in Indonesia ended up at the time of the occupation of the Netherlands, especially during the reign of Governor General
Raffles. At his era, in 1811 the slave trade was banned in Indonesia territory. Slavery was officially abolished in the Indies colonies on January 1, 1860, but slavery still persists in most part of Indonesia, even in some areas until at least the 1940s (Boomgard, 2004).

The term diaspora refers to people who are by forced (traumatic) or voluntarily, living in areas outside their land of birth / own origin, stil emotionally and sentimentally attached with the country and culture of origin. When the Indonesian diaspora began to leave their homeland with various motifs (employment, education, compulsion, weddings, etc.), then a shift in cultural identification between the diaspora with its homeland occurs. Indonesian migrants around the world are Indonesian diaspora. They have a tendency to always bring the culture and values of their home country to the new sites. The Indonesian people are known to have a high spirit of nationalism and strong communal culture. This culture carried over when they migrate to another country. In this process, there is a change in behavior, change in moral values and their worldview. They did not move frontally, but flows in a flexible way, to adapt and then show their existence in a new place.

The efforts of the diaspora to become exist and maintain the original culture in a new place apparently does not always go smoothly. An example is the case of claims Reog dance and the art of Indonesian Batik by Malaysia a few years ago. Later revealed that people who claimed Reog and Batik are also Indonesian descendants. They are mostly Indonesian workers who had migrated to Malaysia long time ago, and they mainly come from the island of Java. Many of those changed their citizenship as Malaysians. These immigrants (the JavaIndonesian diaspora) are very fond with Reog and Batik, same as the Indonesian, especially considering that the island of Java is the origin of the two arts. This proves how Indonesian descents always try to maintain and preserve their native cultures in a new place. It also the same for the Indonesian diaspora in Paris, France.

Mr. Dino Patti Djalal, a former Indonesian ambassador for the United States, he also the initiator of Indonesia Diaspora Congresses, provides five main categories that can be used to classify the Indonesian diaspora (Waizly, 2013), among others:

a. Indonesian diaspora in general, are the Indonesian who live / work / study abroad. Usually, they still have a passport that says they still have Indonesian citizenship and originate from Indonesia.

b. Indonesian diaspora that were naturalized with foreign nationals. Usually they have dual citizenship status or change their status to a new country

c. Indonesian diaspora because of mixed marriages, is where one of the husband or wife are Indonesian descendants and live abroad, followed by their children.

d. Indonesian diaspora who are descendants of the third generation, fourth generation and so on that had never become an Indonesian citizen This usually occurs as a result of mixed marriages. 
e. Indonesian diaspora who had no kinship or relation at all, never born in Indonesia, but very in live with Indonesia. They are sympathizers who have the awareness, knowledge and love of Indonesia, sometimes its exceed those the Indonesian.

Indonesian Diaspora Network, which is the result of the first Congress of Indonesian Diaspora give more modest restrictions on the categorization of the Indonesian diaspora (Hasanah, 2013), as follows:

\section{a. Indonesian citizen who live abroad \\ b. Foreign nationals who have lineage, or Indonesian parent}

c. Foreigners, but has very much love and high dedication to the nation of Indonesia.

From the categorizations above, the scope of a person can be called Indonesian diaspora is actually very broad, and is not limited to birth, or have Indonesian bloodline, or the lineage, even includes love and dedication to the nation of Indonesia. If this definition is used, then the number of the Indonesian diaspora are in accordance with the statement of the Minister of Foreign Affairs, Mr. Marty Natalegawa, as many as 8 million Indonesian diaspora (Kemenlu, 2013).

To dissect this problem, I use the theory of social and cultural identity which are considered relevant. Social identity theory was developed and popularized in 1972 by Henri Tajfel, a social psychologist born in Poland. Together with his student, John Turner, they made a research on social identity, social categorization and social comparison in the relationship between groups. Jeefrey Weeks (in Kinasih, 2007: 4) argues about the importance of identity for individual or group is about belonging, in common with a number of people, and what distinguish themselves with others. Identity is the ability to build a story about him/herselves. Individuals trying to construct a coherent narrative of self-identity that form a developmental trajectory from the past to the future that can be predicted (with questions, such as who am I, what do I do, how to act, and others). Thus, identity is not a collection of properties owned by individuals, but rather what is understood by people in the context reflective biography. Identity is not a trait that we have, not something that we have to be shown, but it is a way of thinking about ourselves. What we think about ourselves often change from one environment to another environment as well as in space and time.

Regarding cultural identity, Stuart Hall (1990) explains that the cultural identity (or ethnicity) can be seen as a form of (or identity as being) and as the process of becoming (identity as becoming). In this sense, cultural identity is a collectively owned entity, it is internal, located in the individuals that have similar socio-historical. The cultural identity is a reflection of the historical equation, codes and cultural values, as a representation of something which then formed a group of individuals as a unit, even though they are different individuals.

Cultural identity is an identity that is owned by a nation linked to culture. In this context, cultural identity can be seen as Indonesian cultural identity. Culinary is often becomes reference in term of cultural identity. In the marketing studies, the brand has an important role to reinforce the product's identity, facilitate the promotion and positioning. For the state, a "nation brand" has the same function, which provides specific representation on the country. The role can be done through efforts to introduce Indonesian culinary abroad. Cultural dinner at Indonesian Embassy in Paris can be seen on fig. 1.

Gastrodiplomacy (Sam Chapple Sokol, 2013) is a concept where culinary (which is also means a nation's cultural wealth) becomes an important diplomatic bridge of nations through an approach to the targeted public. India, Thailand, Japan and Korea are good examples of culinary diplomacy, they succesfully managed to built thousands of the country's typical food restaurants in different parts of the world. Through arts, culture and culinary diplomacy, the Indonesian diaspora constantly trying to show the existence of their national and cultural identity, as well as become a cultural and Indonesia's tourism ambassador abroad. Number of Indonesian diaspora spread in Paris is numerous, of course, this is a potential that must be taken seriously to open the door for promoting Indonesian tourism in general.

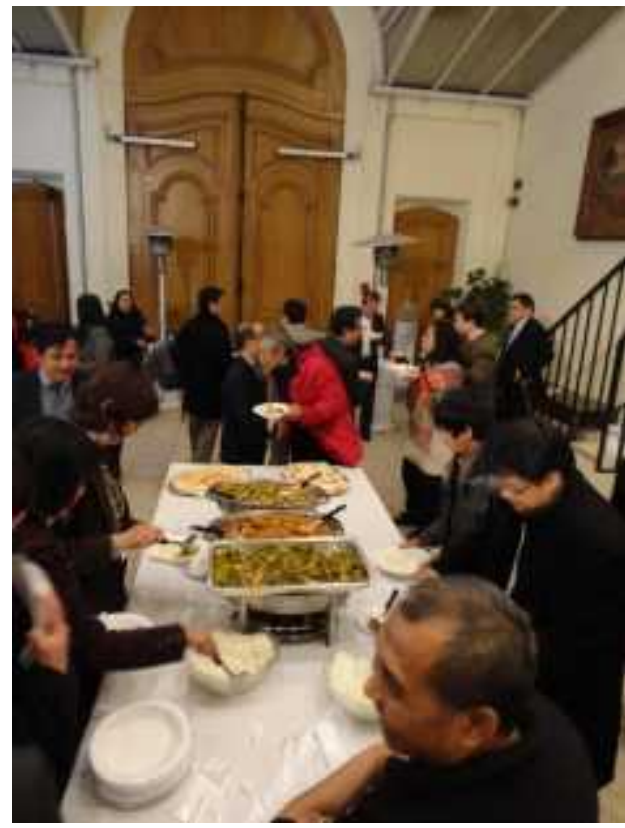

Fig. 1. Cultural dinner at Indonesian Embassy in Paris (private collection)

In 2012, the Ministry of Tourism and Creative Economy of Indonesia set 30 Indonesian culinary icons which represent each regions in Indonesia. The selection criteria include, the ease of getting the materials, widely known by the public, and there are professional cooks who make it (Detikfood, 2012). Indonesian culinary character who tends to be hot and spicy, and lack of presentation apparently does not always correspond to the tastes of Europeans, it is necessary for the taste adjustment and the presentation need more interesting.

The Indonesian diaspora in Paris regularly hosts a variety of meetings, both formal and non formal among its members. These meetings are often attended by the Parisians or the Europeans. On this occasion, the Indonesian traditional foods is 
served. Indonesian culinary playing role as a symbol of nationalism Indonesian diaspora in the city. Some of the food has always been a mandatory menu in these meetings; Nasi Kuning (yellow rice), Nasi Putih (white rice), Nasi Goreng (fried rice), Sate Ayam (chicken satay), Soto Ayam (chicken soup), Ayam Goreng (fried chicken), Rendang, Perkedel Kentang (fried potato cakes) and Krupuk Udang (prawn crackers). Indonesian culinary also served as a media for promoting Indonesian tourism abroad. For example, in the ITB Berlin exhibition, the Indonesia's booth is always crowded with guests who want to know and are interested in culinary Indonesia.

In Paris, there are some restaurants that specialized in selling traditional Indonesian food. The first is "Indonesia" restaurant, which established since 1982. This restaurant is built on the principle of familyhood and mutual cooperation, located in Rue Vaugirard, it has a long story. One of the owners is Sobron Aidit, he was forced to migrated to Paris in 1981 it due to political turmoil in Indonesia. On the weekdays, the restaurant is usually full of Europeans. The restaurant's is filled with ethnic atmosphere and Indonesian traditional ornaments. The menu is written in three languages; Indonesian, English and French, covered by Javanese Wayang (shadow puppets) decoration. They provided Gado-Gado (steamed vegetable with peanuts sauce), Lumpia (spring rolls), Sate Kambing/Ayam (mutton/chicken satay), Beef Rendang, Nasi Kuning (yellow rice) and Cumi Goreng (fried squids). Indonesian typical food by Indonesian students is described on fig.2.

The second restaurant called "Djakarta Bali", located in Rue Vauvilliers. This restaurant has four stars with a score of 3.8 on Tripadvisor. The restaurant was established in 1985, is also full of typical decorations and ornaments of Indonesia, especially from the area of Bali. In the era of 1965, the family owners of the restaurant are political refugees from the Soeharto regime for 33 years. At first, the owner of the restaurant has a mission to create the other kind of "Indonesian Embassy" in Paris, which is dedicated to the promotion of Indonesian through culture, especially through the culinary. The menu offered include Nasi Goreng (fried rice), Sate Ayam (chicken satay in peanuts sauce), Mi Goreng (fried noodles), Lumpia (spring rolls), Ketoprak, Gado-gado, Soto Ayam, Rendang, Kare Ayam (chicken curry) and others. The restaurant also serves a full package of Rijsttafel with various combinations of dishes. The food was presented all free of MSG, which for some people can cause of headaches and allergies. In addition, they regularly performes traditional dances of Bali.

The third restaurant named "D'Jawa", it located in the center of Paris. Unlike the two previous restaurants with strong ethnic style, this restaurant is dominated with orange and white colors, comes with a stylish interior and a way of presenting a more modern and minimalist. The owner of this restaurant is a franco-Indonesian, who has spent 18 years living in Jakarta. Currently there are two branches in the city of Paris. This restaurant uses the method of 'box' and buffet like an Asian fastfood restaurant. In addition, the food is cooked directly in front of visitors, it is once again an interesting attraction. The food was served, among others: Rendang, Opor Ayam, Sate
Ayam (chicken satay), Ikan Rica-Rica, Nasi Goreng, Mi Goreng and Bihun Goreng (fried vermicelli). In addition to those restaurants, there are several Asian restaurants also provide Indonesian typical food, among others: Black Pinky, Le Sarawan, Makassar Lounge and Restaurant, and Mama Bali.

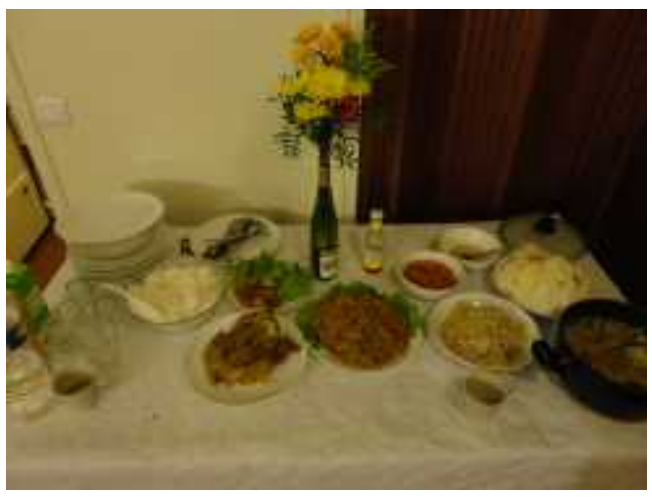

Fig. 2. Indonesian typical food by Indonesian students (private collection)

In addition, at the Embassy of Indonesia in Paris, there is a cafeteria managed by Indonesian lady. The cafetaria provided a variety of food. It provides rice, chili sauce, soy sauce, ketchup, condiments, tempeh, instant noodles, crackers, and even some typical brands of Indonesian cigarettes. Here, longing for Indonesian dishes seemed relieved when the diaspora Indonesia visit there. Based on observations, in addition to the Indonesian diaspora, the shop is often visited by Europeans who love Indonesian cuisine.

Sekar Jagat, is a well known Indonesian diaspora community living in Paris, and they focused on culture and dances of Indonesia. This art community is quite popular in the city of Paris, and often invited to perform in various cities in France, Netherland and Belgium. Sekar Jagat's members at least 55 people, consists of various backgrounds and profession. Among its members, there are native Indonesians, their descents and some Europeans who cherish the culture of Indonesia. Member of Sekar Jagat Paris making Sate Ayam in their garden party is discribed on fig. 3 .

This community organizes regular meetings and dance practice every week. Whenever meetings were held, each member must bring a traditional Indonesian dishes were then enjoyed together by its members. Here, Indonesian culinary played a major role in building a cultural identity, a source of pride and increase the sense of unity and nationalism of itys members. 


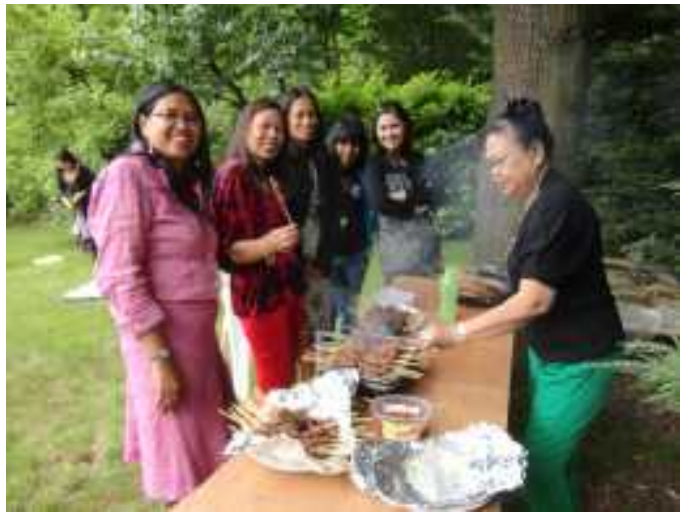

Fig. 3. Member of Sekar Jagat Paris making Sate Ayam in their garden party (private collection)

One organization that has great merit in Indonesian culinary diplomacy in Paris is PPI (Perhimpunan Pelajar Indonesia or Indonesian Student Association). PPI is an organization of Indonesian students who continue their studies in France, either to take the diploma, master or doctoral program. PPI was founded in 1958, and nowday there are 20 PPIs in all regions of France. PPI members approximitely around 450 Indonesia students. PPI actively organize events which capable of promoting the art and culture of Indonesia. Oftenly, they conduct events that involved the public of Paris. In the activities they organized, the culinary aspect is always there and its become a favorite.

\section{CONCLUSION}

Indonesia diaspora who migrated to Europe, especially in Paris, are still trying to maintain a sense of nationalism and their love of the homeland in various ways. They are the actors who become pillars of the implementation of the Indonesian culinary diplomacy. The Indonesian diaspora is not only indigenous Indonesian, but also including their descendants and the foreigners who loves Indonesia. Indonesia has a very large number of diaspora around the globe, its a potential that can be fully utilized. Indonesian culinary proved to be a sense of brotherhood, and can strengthtening emotional bonds. Besides, Indonesian culinary also managed to establish the pride of Indonesia's cultural identity, which also contributed positively to the promotion of tourism in Indonesia.

\section{REFERENCES}

Appadurai, Arjun. (1996). Modernity at Large:

Cultural Dimensions of Globalization Public Words1. Minneapolis: University of Minnesota Press.

Boomgaard, P. (2004). 'Human Capital, Slavery and Low Rates of Economic and Population Growth in Indonesia, 1600-1910'. in Gwyn Campbell (ed). 2004. Studies In Slave And Post-Slave Societies And Cultures. England: Frank Cass Publishers.

Detikfood. (2012). Ini Dia 30 Ikon Kuliner Tradisional Indonesia http://food.detik.com/ $\mathrm{read} / 2012 / 12 / 17 / 141546 / 2120507 / 297 /$ ini- dia-30ikon-kuliner- tradisional- indonesia-
Forbes. (2006). Priciest Coffee Bean in http://www.forbes.com/2006/07/19/priciest- coffee beans_cx_hl_0720featA_ls.html

France 24. (2009). Indonesians make themselves at home in Paris Embassy. from http://www.france24.com/en/20090916-indonesiansmake-themselves-home-paris- embassy-

Guillon, M. (1998). "The Chinese and Chinese in Paris" (Chapter 11).

Hasanah, St. Muthia. 2013. Peranan Task Force Diaspora Terhadap Diplomasi Kuliner Indonesia di Luar Negeri. Skripsi. Fisipol. UniversitasHasanudin in http://grfdt.com/EventDetails.aspx?Type=Events\&TabId $=30$.

Hong Kong University Press, Hague Journal of Diplomacy, 8 (2).

In: Sinn, Elizabeth (editor). The Last Half Century of Chinese Overseas. Hong Kong University Press, Hague Journal of Diplomacy, 8 (2).

Kemenlu. (2013). Minister of Foreign Affairs Marty: Diaspora "Spirit in Line with Indonesia's Foreign Affairs Politics" in http://www.kemlu.go.id/ jeddah/Pages/ News.aspx? IDP $=6382 \& \mathrm{l}=\mathrm{en}$

Kinasih, A. W. (2007). Identitas Etnis Tionghoa di Kota Solo.Yogyakarta: Laboratorium Jurusan Ilmu Pemerintahan FISIP UGM

Kompas. Kaji Pertimbangan Sejarah: Naskah Akademis Status Dwiwarga Negara Bisa Diajukan. Tuesday August 20,2013, p.10.

Natalegawa, Marty. (2013) in Setkab. 2013. "3800 Diaspora Indonesia 'Pulang Kampung' Ikuti Kongres di Jakarta" Press Conference. http://setkab.go.id/berita-9890-3800diaspora-indonesia-pulang-kampung-ikuti- kongresdi-jakarta.html

Rahardjo, Mudjia. (2010). Diaspora dalam Pergeseran Budaya dan Bahasa. http://mudjiarahardjo.com/artikel/213-diaspora-dalampergeseran-budaya-dan-bahasa.html.

Robin Cohen. (1997). Global Diasporas: An introduction. Routledge

Sam Chapple-Sokol. (2013). Culinary Diplomacy: Breaking Bread to Win Hearts and Minds. The Hague Journal of Diplomacy, 8 (2). p. 161-183

Singh, Amit. GRFDT Seminar Series. "Indian Diaspora: Emerging Issues and Challenges" http://grfdt.com/EventDetails.aspx?Type=Events\&TabId $=30$

Stuart, H.(1990). Cultural Identity and Diaspora. London.

Tempo. (2015). Memanfaatkan Diaspora Indonesia. in http://www.tempo.co/read/opiniKT/2015/08/11/10672/m emanfaatkan-diaspora- Indonesia.

TravelCNN. (2016). Worlds' 50 Most Delicious Food. http://travel.cnn.com/explorations/eat/reade rschoice-worlds-50-most-delicious-foods012321/ retrived 8 November 2016

Vink, Markus. (2003). 'The World's Oldest Trade": Dutch Slavery and Slave Trade in the Indian Ocean in 
the Seventeenth Century'. Journal of World History, Vol. 14, No. 2. University of Hawai 'i Press

VOC 1276, OBP 1671, fls. 684-1007, Notitie [Speelman] . . tot Naerrichtinge voor den Ondercoopman Jan van Opijnen, 17.2.1670; J. Noorduijn, "De Handelsrelaties van het Makassaarse Rijk Volgens de Notitie van
Cornelis Speelman uit 1670," Nederlandse Historische Bronnen III (Amsterdam, 1983), pp. 96-123. dalam Vink, 2003 Op.

Waizly, D. (2013). 5 Kategori Diaspora Indonesia.http://themarketeers.com/archive s/ 5kategori- diaspora-indonesia .html \#.Uj-DgBZsXSM 